\title{
A Study Aiming To Determine The Effect Of Quality Of Work Life Perception Of Workers Of Tourism Sector On Their Intention Of Staying At Their Job
}

\author{
Dr. Şevket Yirik \\ Akdeniz University Faculty of Tourism \\ sevketyirik@gmail.com \\ Serap Babür \\ Pamukkale University, Tourism Faculty, \\ Tourism Management Department \\ serapbabur07@hotmail.com
}

DOI:10.5901/mjss.2014.v5n19p54

\begin{abstract}
Quality of work life should be improved in order to keep up with the changes in the world, reduce work stress, increase efficiency and competition and benefit workers. The purpose of this study is to determine the effect of quality of work life perceptions on the intention to stay at the job. First of all, literature has been reviewed. A questionnaire has been applied on 474 participants in total who work in tourism sector. Obtained data have been analyzed with SPSS statistics software. Study's structural validity has been proved through explanatory factor analysis. Result of the study showed presence of a positive relation between quality of work life factors and dimension of intention towards staying at the job.
\end{abstract}

Key Words: Tourism,/Work / Work Life/ Quality of Work Life / Intention to Stay at the Job

\section{INTRODUCTION}

Work life has an important place in the life of workers. Since performing a certain job would take up some time, work life is also important in terms of psychology. Work has important properties in workers life such as spending time, directing life energy to useful purposes and protecting mental health through satisfaction by doing so. In recent years, concept of quality of work life began to refer to providing satisfying work conditions for workers. This concept provides physical and psychological benefits to workers by creating better working conditions through some changes in the current working environment, by doing so it positively contributes to worker's dignity; in other words it is a management approach with a focus on worker. (Öğe, 2000: 67-68)

Quality of work life is understood as agreeableness or disagreeableness of working environment from the perspective of workers. Since main purpose of a business is productivity, it is important to develop a working environment for the workers to make them feel comfortable and to improve their efficiency (Davis, 1981: 330).

Most of the studies that suggest quality of work life has an effect on workers' intention to stay at the job, put forth that issues such as insufficient organizational support, perceived injustice, mistrust of workers to the organization and managers are proven to have an effect on the intention of the workers to quite their job (Aryee, Budhwar and Chen, 2002; Hian and Einstein, 1990; Huzzard, 2003). Improving working conditions of workers, enables success in business. The job's quality would increase inevitably as a result of efficiently working employees. Therefore, quality of work life is understood as one of the most important subjects from the perspective of workers and also managers.

\section{Quality of Work Life}

The term quality of work life (QWL), sometimes referred as "working life quality", is translated to Turkish as "çalışma yaşam kalitesi" (ÇYK) but other expressions are also used to transfer the meaning of working life quality, qualification of work life, 
humanization of work life/job. In addition to this, different concepts are being used in many countries; some of the examples are: "improvement of work life" in France or Francophone countries, "protection of workers" in socialist countries, and "democratization of working environment and workplace" in Scandinavian countries (Dikmetaş, 2004: 56).

Quality of work life is a concept that broad in scope, its limits are fuzzy and its perception and definition varies in time according to countries, regions, even sectors within the same country, its content and priorities may differ from person to person also (Schulze, 1998: 528).

Newstrom and Davis $(1997,293)$ define quality of work life as everything to be found in workplace which is in favor of workers and against them. This definition is important since it considers quality of work life as extensive. QWL's domain contains improvement of worker's skills, wage, health, work satisfaction, improvement of physical conditions as well as issues that negatively effect worker such as alienation to job, stress, fatigue (Newstrom and Davis, 1997: 293).

While Graber argues that objective indications of behavioral consequences other than job satisfaction such as absence, quitting the job and efficiency should also be used within the quality of work life's scope; Seashore argues that personal differences such as skills, values and expectations should also be evaluated within the frame of this concept (Araz, 1991: 14-15).

\section{Dimensions of Quality of Work Life}

Quality of work life typically involves eight sub dimensions. These are: safe and secure working conditions, provision of opportunities to improve and use individual capacity (skill improvement and utilization opportunities), provision of opportunities for continuous development and security directed towards future (continuous development and improvement opportunities), social integration within the organization, workers' rights of personal immunity, liberty of expression and equality (laws within the organization), balance of worker role within the organization and other roles individual has in life (spheres of working life and private life), work organization with social responsibilities (social dimension of work life), adequate and fair salary (Solmuş, 2000: 37-38; Şimşek et al., 2001: 137-138; Özkalp and Kırel, 2001: 553, Erginer, 2003: 207-211.)

\section{Programs to Improve Quality of Work Life}

Efforts to implement programs to improve quality of work life within the scope of "socio-technique" organization and management system in order to provide productivity and high product quality play an important role in constituting today's management, organization and work structures. For quality of work life is a multi-dimensional or systematic approach in forming series of beliefs and values that affect every aspect of the organization (Can, 1991: 89). The intention to stay at the job refers to the worker's state of staying in the same business willfully and thoughtfully.

While organizational efforts have a positive effect on the worker's staying at the job, mid level managers have an effect on worker's decision to quit the job. Organizational efforts creates loyal worker for these managers in time and this constitutes the reason for workers' tendency to stay at the job (Chen, 2001: 655).

\section{Relation between Quality of Work Life and Intention of Staying at the Job}

Choice of human resources, success evaluation, carrier planning, salary system, system of motivation and reward, training and development programs, work programs, programs which constitute the basis of human resources management are important factors in improving QWL. Job design is considered as a QWL program and thought of as having a motivational aspect in increasing worker's loyalty to organization (Garg and Rastogi, 2006; Yüksel, 1998).

According to Normala (2010) there is a strong and positive relation between QWL and loyalty of workers to the organization they work for. From this point, it is possible to say that workers with high QWL will be more loyal to the organization they work for (Normala, 2010: 77).

Harmonization of people's capacities and physical structure of their working environment, productive, safe and comfortable operation of organizational equipment, materials, machines and working system cause increase of trust in workers for the organization and solidify their intention to stay at the job (Meister, 2001; Genaidy et al, 2002). 
Study Aiming to Determine the Effect of Quality of Work Life Perception of Workers of Tourism Sector on Their Intention of Staying at Their Job

Aim, Importance and Method of the Study

The purpose of this study is to determine the effect of quality of work life perceptions of workers on their intention to stay at the job. Below questions were asked in order to realize the aim of the study.

According to workers of tourism sector, how is quality of work life in tourism sector?

Do opinions of workers of tourism sector on quality of work life and their intention to stay at the job differ meaningfully according to demographic data?

Do perceptions of quality of work life have an effect on the intention of workers to stay at the job?

With this study, the effect of quality of work life perceptions of workers of tourism sector on their intentions to stay at the job has been determined. The identification of quality of work life perceptions of workers and their intentions to stay at the job is expected to contribute to efforts towards resolution of issues regarding workers of tourism sector. The universe of this study is constituted of all people working in tourism sector in Antalya. The results obtained are thought to provide important tips for the workers and managers of tourism sector.

Questionnaire has been utilized as data collection tool. Questionnaire is constituted of three sections. First section consists of "Personal Information Scale" aimed at defining personal properties of participants of the survey, second section consists of "Quality of Work Life Scale" which is developed by researcher and aimed at measuring qualities of work life of workers of tourism sector. Scale has been prepared in four dimensions consisting of work life balance, social factors, economical factors and content of job in order to measure QWL of workers of tourism sector.

\section{Quality of Work Life Scale}

Kaiser-Meyer-Olkin sampling sufficiency of the scale has proven to be 0.911 . This value shows that data is suitable for factor analysis. Reliability analysis of the scale which was performed on the dimensions obtained in factor analysis conducted with 25 variables resulted in reliability coefficient (Cronbach Alpha) of 0.919 . 4 factors resulted from analysis, these are respectively: content of job, social factors, work life balance and economical factors. Obtained 4 factors explain $59.225 \%$ of total variance. Bartlett test value has proven to be $0.000(p<0.05)$, and this shows that correlation between variables is meaningful. Table 1 shows values of internal consistency (cronbach alpha) of factors. Reliability coefficients of factors which were calculated by Cronbach Alpha are between 0.803 and 0.901 . Values in question were proven to be at an acceptable level.

And third section of the questionnaire consists of "Scale of Intention of Staying at the Job" aimed at measuring workers' Intentions of Staying at the Job.

\section{Demographics of Participants}

As seen in Table 1. 474 workers in total participated in the survey. Demographic profile of participants is given in Table 2.

We can summarize socio-demographic properties of organization employees in the scope of the study as follows. Of 474 workers in total; $37 \%$ female, $63 \%$ male; department of study $67 \%$ travel management, $38 \%$ hospitality management and $1 \%$ food \& beverage management; grade $1 \%$ second grade, $47 \%$ third grade, $52 \%$ forth grade. Graduated high school of workers; 47\% Vocational Hotel Management and Tourism High School, 4\% Vocational High School for Girls, 8\% MultiProgram High School, 27\% Private-High School and 23\% other high schools; 98\% of workers have worked in tourism sector before and $1 \%$ have not. $40 \%$ of workers have worked in tourism sector for $1-3$ years, $38 \%$ for $4-6$ years, $21 \%$ for 7 9 years and $0.2 \%$ for 10 years and more. $2 \%$ of workers did internship for $0-40$ days, $14 \%$ for $40-80$ days, $28 \%$ for $80-120$ days and $57 \%$ for more than 120 days. Predominant sector of internship of workers were: $29 \%$ food and beverage, $2 \%$ sales and marketing, $8 \%$ reservation, $17 \%$ front desk, $20 \%$ operation, $7 \%$ accounting, $2 \%$ guest relations, $1 \%$ housekeeping, $1 \%$ human resources, $1 \%$ ticket sales and $1 \%$ animation.

Quality of Work Life and Intention of Staying at the Job And Workers' Intention of Staying at the Job 
As seen in Table 2. According to results of descriptive statistics concerning intention of staying at the job, the highest average (2.398) belongs to the group whose expectations about work life are met, while the lowest average (2.094) belongs to the group who would not prefer to work in any other sector than tourism. When analyzed, the averages remaining above 2 and close to 3 indicates that workers have a negative perception in general about staying at the sector.

\section{Relation between Quality of Work Life and Intention of Staying at the Job}

Correlation analysis is utilized when a study concerning direction and force of relation between two variables is desired to be performed. As results of analysis, values close to 0 indicate a direct and weak relation between two variables while values close to 1 indicate a direct and strong relation between two variables (Bayram, 2004: 115). Degrees of relation of correlation coefficients: 0 no relation, 01-10 very weak, 11-20 relatively very weak, 21-30 weak, 31-40 relatively weak, 4150 slightly weak, 51-60 slightly strong, 61-70 relatively strong, 71-80 strong, 81-90 relatively very strong, 91-100 very strong (Nakıp, 2003: 322).

When results of analysis examined, positive and meaningful relations at the level of 0.001 have been found between all the dimensions. When table is examined, the strongest relation is found between quality of work life and content of job dimensions ( $r=.657)$. On the other hand, the weakest relation is found between intention of staying at the job and social factors $(r=.311)$.

\section{Correlation Analysis Concerning Quality of Work Life and Intention of Staying at the Job}

As seen in Table 3. When correlation analysis results are examined it is seen that correlation coefficient numbers are not above 0.85 . This also shows that the study has discrimination validity. By this way, after structural validity has been proved by factor analysis, discrimination validity is proven by correlation analysis.

Regression analysis has been conducted in order to determine the effect of quality of work life perceptions of workers on their intentions of staying at the job. The result of anova analysis aimed at determining whether or not model is statistically meaningful, was $F=35.102, p=0.000$ and this value has been found to be meaningful statistically at the significance level of $1 \%$. R2 value concerning analysis has been found to be 0.230 . In other words, $23 \%$ of quality of work life variables are explained by intention of staying at the job variable $(R=.480, R 2=.230, P<0.01)$. This percentage shows that quality of work life perceptions of workers have a small effect on their intentions of staying in the sector. When we look at the results with regard to Durbin-Watson test, the value is determined as 1.824 in the study. Durbin-Watson value indicates that there is no autocorrelation in the model if it is in the range of 1.5-2.5.

Table 4 shows which factors of quality of work life have a bigger effect on intention of staying at the job and which factors do not have any effect.

\section{Multiple Regression Analysis Concerning Factors of Quality of Life Which Effects Intention of Staying at the Job}

In Table 4, the standardized regression coefficients ( $\beta$ ) of independent variables which are present in the study, and $t$ and $p$ values concerning their meaningfulness have been given.

When Table 5 is analyzed, the most effective factor of quality of work life perceptions of workers on intention of staying at the job is found to be "social factors". According to regression coefficient which is standardized to test the predictive power of independent variables concerning intention of staying at the job, social factors, economical factors $(p<0.01)$ and work life balance $(p<0.05)$ have been observed to be meaningfully predictive on intention of staying at the job. It is also observed that content of job does not have a statistically meaningful effect on intention of staying at the job.

In conclusion, conducted regression analysis shows that quality of work life factors have an effect on intention of staying at the job, although small.

Independent sample $t$ test analysis has been conducted concerning the relation of demographic variables with quality of work life perceptions and intentions of staying at the job of people who work in tourism sector. The results of $t$ test analysis in question are given in Table 5.

\section{"Independent Sampling T Test" Analysis Results Concerning Gender Variable of Survey Group}

Analyzing the relation gender has to the relation between quality of work life and intention of staying at the job in a more detailed way has been considered more beneficial and independent sampling t test has been applied with this purpose. As seen in Table 5, only in work life balance perception of workers a significant difference according to gender has been found 
at 0.05 . Other than this, no significant difference have been found in dimensions of content of job, social factors, economical factors and intention of staying at the job.

Secondly; data have been analyzed by one way anova test in order to find out whether there is a difference in quality of work life perceptions and the intentions of staying at the job with regard to independent variables of "studied department", "age", "grade" and "graduated high school".

Findings Concerning Differences of Participants' Quality of Work Life and Intentions of Staying at the Job According Their Demographics

As seen in Table 6, grades, graduated high schools and studied departments do not create a significant difference in participants' quality of work life perceptions and intentions of staying at the job. Nonetheless, at the dimension of economical factor, ages of participants show a significant difference at the level of 0.05 .

\section{Conclusion and Suggestions}

Findings of this study show that workers' quality of work life perceptions and intentions of staying at the job are correlated. In the scope of this study, the most effective factor of quality of work life perceptions of workers of tourism sector on intention of staying at the job is found to be "social factors". Human is a social being and would desire psychological satisfaction in workplace too. This is why workers' intention of staying at the job is closely related to having good friendships at workplace, working in a respectful manner and with a team spirit, attending social organizations at workplace and having opportunities to improve themselves. Factors of content of job and work life balance are less prioritized by workers who are happy and psychologically satisfied in workplace.

Tourism is especially a labor intense sector and when factors such as seasonality, irregular working hours, qualified worker problem, high labor turnover rate are considered, the effect of social factors have on intention of staying at the job is very meaningful. Workers, who are not satisfied psychologically and socially at the place of work, could have the desire of quitting their job even though the salaries are high. In this sense, employers should interpret this well. Employers should organize social activities for their employees and contribute to social integration among workers in the organization.

Other factors of quality of work life perceptions of workers which have effect on intention of staying at the job are economical factors and work life balance. Content of job however, does not have an effect on intention of staying at the job. Looking from this perspective, it is concluded that for people who work in tourism sector, social factors in workplace are more effective on intentions of staying at the job than the actual job they perform.

As a result of multiple regression analysis conducted in the scope of the study, it is found that quality of work life perceptions of workers of tourism sector have an effect of $23 \%$ on intention of staying at the job.

According to the results of the analyses conducted, it is concluded that genders, grades, graduated high schools and studied departments do not create a significant difference in participants' quality of work life perceptions and intentions of staying at the job.

Priorities with regard to QWL increase, humanization of the job are determined within the unique conditions of every organization. However, first step to humanize the job could be providing for psychological and social needs of workers and improving working conditions in tourism sector. Thus, with fulfilled psychological and social needs, workers' intentions of staying at the job as well as their loyalty to organization will increase.

The results of study have to be considered by tourism sector. Understanding the importance of the effect of quality of work life on intention of staying at the job is considered to be a contribution to the sector.

\section{REFERENCES}

Aryee, S., Budhwar, P.S. ve Chen, Z.X. (2002), "Trust as a Mediator of the Relationship between Organizational Justice and Work Outcomes: Test of a Social Exchange Model" Journal of Organizational Behavior, 23(3): 267-285.

Araz, Arzu. (1991), "Kişisel Projelerde Hareketle İşletme Yöneticilerinin İ̧ Yaşamı Kalitesi”, Yayınlanmamış Yüksek Lisans Tezi, Ege Üniversitesi Sosyal Bilimler Enstitüsü, İzmir.

Can, A. (1991), "Çalışma Hayatının Kalitesinin Geliştirilmesi", I. Verimlilik Kongresi, (27- 29 Kasım), MPM Yayınları: 454: 89-99. 
Dikmetaş, E. (2006), "Hastane Personelinin Çalışma/lş Yaşam Kalitesine Yönelik Bir Araştırma", Ç.Ü. Sosyal Bilimler Enstitüsü Dergisi, 15(2): 169-182.

Erginer, A. (2003), "İ̧̧ Yaşamının Niteliği (Quality of Work Life), Yönetimde Çağdaş Yaklaşımlar Uygulamalar ve Sorunlar" (Ed. C., Elma ve K, Demir)'de, Anı Yayıncılık, 2. Baskı, Ankara.

Garg, P. ve Rastogi, R. (2006) "New Model of Job Design: Motivating Employees' Performance" Journal of Management Development, 25(6): 572-587.

Genaidy, A., Abdallah, S., Salem, O., Karwowski, W. ve Shel, R. (2002) "The Fundamentals of Work System Compatibility Theory: An Integrated Approach to Optimization of Human Performance at Work", Theoretical Issues in Ergonomics Science, 3(4): 346-368.

Hian, C.C. ve Einstein, W.O. (1990), "Quality of Work Life (QWL): What Can Unions Do?" SAM Advanced Management Journal, 55(2): 17-22.

Huzzard, T. (2003), "The Convergence of the Quality of Working Life and Competitiveness", National Institute for Working Life, Stockholm.

Meister, D. (2001) "Basic Premises and Principles of Human Factors Measurement" Theoretical Issues in Ergonomics Science, 2(1): 1-22.

Newstrom, J. W. ve Davis, K. (1997), "Organizational Behavior Human Behavior At Work (10. Edition), Mcgraw-Hill.

Özkalp E. ve Kırel, Ç. (2001), "Örgütsel Davranış", Anadolu Üniversitesi Eğitim, Sağlık ve Bilimsel Araştırma Çalışmaları Vakfı Yayın No: 149, Etam A.Ş. Matbaa Tesisleri, Eskişehir.

Öge, Serdar, H. (2000), "Örgütsel Etkinliğin Sağlanmasında İşgören - İ̧̧ Uyumunun Ergonomik Analizi", Yayınlanmamış Doktora Tezi, Selçuk Üniversitesi Sosyal Bilimler Enstitüsü, Konya.

Schulze, N. (1998), "Yaşam Kalitesini Yükselten Temel Unsur Olarak İşin İnsancıllaştırılması", MPM Yayınları No: 622, Altıncı Ergonomi Kongresi, Ankara. MPM Ankara Üniversitesi, 27 - 29 Mayıs 1998, Mert Matbaası, 519 - 531.

Solmuş, T. (2000), "İ̧ Yaşamında Kalite Ve Kaliteyi Arttırmaya Yönelik Program”, Türk Psikoloji Dergisi, 18, (Eylül).

Şimşek, M.Ş., Akgemici T. ve Çelik A. (2001), "Davranış Bilimlerine Giriş ve Örgütlerde Davranış", Nobel Yayın Dağıtım Ltd. Şti., Genişletilmiş 2.Basım, Ankara.

Yüksel, Ö. (1998), "İnsan Kaynakları Yönetimi”, Ankara, Gazi Kitabevi.

Table 1. Demographic Profile of Participants

\begin{tabular}{llllll}
\hline Gender & $\begin{array}{l}\text { Frequen } \\
\text { cy }\end{array}$ & & Predominant Section of Internship Frequency & \\
\hline Female & 175 & 37 & Food \& Beverage & 139 & 29,3 \\
\hline Male & 299 & 63 & Service-Bar & 55 & 11,6 \\
\hline Total & 474 & 100 & Sales-Marketing & 9 & 1,9 \\
\hline Department & 289 & 61 & Reservation & 38 & 8 \\
\hline Travel Management & 182 & 38,4 & Operation & 82 & 17,3 \\
\hline Hospitality Management & 3 & 0,6 & Accounting & 93 & 19,6 \\
\hline Food \& Beverage Management & 474 & 100 & Guest Relations & 34 & 7,2 \\
\hline Total & & & Housekeeping & 3 & 1,5 \\
\hline Grade & 5 & 1,1 & Human Resources & 5 & 0,6 \\
\hline Grade & 221 & 46,6 & Ticket Sales & 5 & 1,1 \\
\hline Grade & 248 & 52,3 & Animation & 4 & 0,8 \\
\hline Grade & & & & & 1,1 \\
\hline
\end{tabular}




\begin{tabular}{llllll}
\hline Total & 474 & 100 & Total & 474 & 100 \\
\hline & & & \multicolumn{2}{l}{ Term of Employment in Tourism Sector } \\
\hline Graduated High School & & & Between 1-3 years & 189 & 39,9 \\
\hline Vocational Hotel Man.\&Tourism & 225 & 47,5 & Between 4-6 years & 182 & 38.04 \\
\hline Vocational School for Girls & 21 & 4,4 & Between 7-9 years & 102 & 21,4 \\
\hline Multi-Program High School & 39 & 8,2 & 10 years and more & 1 & 0,2 \\
\hline Private-High School & 81 & 17,1 & Total & 474 & 100 \\
\hline Other & 108 & 22,8 & Term of internship & & \\
\hline Total & 474 & 100 & $0-40$ days & 10 & 2,1 \\
\hline Condition of Having Worked in Tourism Previously & $40-80$ days & 64 & 13,5 \\
\hline Yes & 468 & 98,7 & $80-120$ days & 131 & 27,6 \\
\hline No & 6 & 1,3 & More than 120 days & 269 & 56,8 \\
\hline Total & 474 & 100 & Total & 474 & 100 \\
\hline
\end{tabular}

Table 2. Explanatory Statistics Related to Intention of Staying at the Job

\begin{tabular}{lll}
\hline Variables & Average & Standard deviation \\
\hline Tourism sector meets my expectations about work life. & 2,094 & 0,841 \\
\hline I would not prefer to work at any other sector than tourism. & 2,398 & 0,749 \\
\hline
\end{tabular}

Table 3. Correlation Analysis Concerning Quality of Work Life and Intention of Staying at the Job

\begin{tabular}{llllll}
\hline Dimensions & 1 & 2 & 3 & 4 & 5 \\
\hline 1. Content of Job & 1 & & & & \\
\hline 2. Social Factors &, $342^{* *}$ & 1 & & & \\
\hline 3. Work Life Balance &, $657^{* *}$ &, $472^{* *}$ & 1 &, $454^{* *}$ & 1 \\
\hline 4. Economical Factors &, $374^{* *}$ &, $400^{* *}$ &, $344^{* *}$ &, $327^{* *}$ & 1 \\
\hline 5. Intention of Staying at the Job &, $364^{* *}$ &, $311^{* *}$ & & &
\end{tabular}

Table 4. Multiple Regression Analysis Concerning Factors of Quality of Life Which Effects Intention of Staying at the Job

\begin{tabular}{lllll}
\hline Dependent Variable & Independent Variables & Beta Value & T Value & P Value \\
\hline & Content of Job &, 106 & 1,958 &, 051 \\
\cline { 2 - 5 } & Work Life Balance &, 097 & 2,048 &, $041^{*}$ \\
\cline { 2 - 5 } & Social Factors &, 272 & 4,629 &, $000^{* *}$ \\
\hline
\end{tabular}




\begin{tabular}{lllll}
\hline Intention of Staying at the & Economical Factors &, 126 & 2,672 &, $008^{* *}$
\end{tabular}

Job

${ }^{* *} p<0.01$

* $p<0.05$

Table 5. "Independent Sampling T Test" Analysis Results Concerning Gender Variable of Survey Group

\begin{tabular}{|c|c|c|c|c|c|}
\hline Dimensions & Variables & $\mathrm{N}$ & $\bar{X}$ & $\mathrm{~T}$ & $P$ \\
\hline \multirow{2}{*}{ Content of Job } & Female & 175 & 3,53 & \multirow{2}{*}{,- 026} & \multirow{2}{*}{,979 } \\
\hline & Male & 299 & 3,53 & & \\
\hline \multirow{2}{*}{ Social Factors } & Female & 175 & 3,19 & \multirow{2}{*}{ - } & \multirow{2}{*}{,439 } \\
\hline & $\begin{array}{l}\text { Male } \\
\end{array}$ & 299 & 3,12 & & \\
\hline \multirow{2}{*}{ Work Life Balance } & Female & 175 & 2,95 & \multirow{2}{*}{2,790} & \multirow{2}{*}{, $005^{*}$} \\
\hline & $\overline{\text { Male }}$ & 299 & 2,70 & & \\
\hline \multirow{2}{*}{ Economical Factors } & Female & 175 & 2,60 & \multirow{2}{*}{,-- 794} & \multirow{2}{*}{,428 } \\
\hline & Male & 299 & 2,67 & & \\
\hline \multirow[b]{2}{*}{$\begin{array}{l}\text { Intention of Staying at the } \\
\text { Job }\end{array}$} & Female & 175 & 1,73 & \multirow[b]{2}{*}{,- 658} & \multirow[b]{2}{*}{, 511} \\
\hline & Male & 299 & 1,77 & & \\
\hline
\end{tabular}

Table 6. Findings Concerning Differences of Participants' Quality of Work Life and Intentions of Staying at the Job According Their Demographics

\begin{tabular}{lllll}
\hline \multicolumn{1}{c}{ Dimensions } & Grade & Graduated High School & Studied Department \\
\hline Content of Job &, 234 &, 343 & 0,81 &, 133 \\
\hline Social Factors &, 068 &, 441 &, 205 &, 388 \\
\hline Work Life Balance &, 341 &, 842 &, 366 &, 494 \\
\hline Economical Factors &, $013^{*}$ &, 359 &, 472 &, 416 \\
\hline Intention of Staying at the Job &, 393 &, 474 & 0,12 &, 521 \\
\hline * $<<0.05$ & & & &
\end{tabular}

